\title{
Instytucjonalne formy wsparcia osób z niepełnosprawnościami w procesie kształcenia na poziomie wyższym - studium przypadku
}

\begin{abstract}
Streszczenie
Problematyka niniejszego opracowania oscyluje wokół szans i ograniczeń związanych z funkcjonowaniem polskiego systemu wsparcia procesu kształcenia osób z niepełnosprawnościami na poziomie akademickim. Zadaniem uczelni jest stwarzanie warunków do pełnego udziału w tym procesie, wykształcenie wyższe stanowi krok do pełnej aktywizacji i uczestnictwa w życiu społeczno-zawodowym. W części teoretycznej przedstawione zostały uwarunkowania instytucjonalno-prawne inkluzyjnej polityki kształcenia, w tym analiza porównawcza obowiązującego Prawa o szkolnictwie wyższym oraz założeń Ustawy 2.0. W części praktycznej przedstawiono model systemu wsparcia na przykładzie wybranej uczelni wyższej. Zakończenie zawiera wnioski i rekomendacje dotyczące planowanych zmian prawnych.
\end{abstract}

Słowa kluczowe: szkolnictwo wyższe, niepełnosprawność, studenci z niepełnosprawnościami

\section{Institutional instruments supporting people with disabilities in higher education: a case study}

\begin{abstract}
This paper focuses on the opportunities and challenges of the Polish education system for people with disabilities. To support academic education process, the task of the university is to create conditions which will allow students with disabilities to gain higher education. This will be a step forward into accommodating and participating in social and, most importantly, professional life. The theoretical part presents the institutional and
\end{abstract}

\footnotetext{
1 Zespół ds. Obstugi Studentów i Doktorantów z Niepetnosprawnością, Uniwersytet Wrocławski.
} 
legal conditions of the inclusive education policy, including a comparative analysis of the current legislation and Act 2.0. In the practical part, the model of the support system is presented as a case study on the example of a selected university. The conclusion contains suggestions and recommendations regarding planned legal changes.

Keywords: higher education, disability, students with disabilities

Zagadnienie niepełnosprawności jest coraz bardziej obecne w polskiej przestrzeni publicznej. Stanowi przedmiot zainteresowania polityków, dziennikarzy, akademików, społeczników. Również bieżące wydarzenia w kraju, takie jak tegoroczny strajk opiekunów dorosłych osób z niepełnosprawnościami w Sejmie, skupiają uwagę wokół działań podejmowanych na rzecz pogłębiania inkluzji społecznej. Polityka publiczna w obszarze kształcenia akademickiego osób z niepełnosprawnościami nie może pozostać obojętna wobec tego wyzwania. Dlatego projekt nowej ustawy o szkolnictwie wyższym i nauce, zwanej Ustawą 2.0. lub Konstytucją dla nauki (Rządowy projekt..., 2018), wdrażający reformę nauki i szkolnictwa wyższego, także odnosi się do kwestii niepełnosprawności.

Problematyka niepełnosprawności w kształceniu była i jest obecna w wielu koncepcjach teoretycznych - od nauczania integracyjnego, przez edukację włączającą (inkluzyjną), politykę równych szans, ideę uniwersytetów otwartych i uniwersytetów dla wszystkich, trzecią misję uczelni, do zarządzania różnorodnością i projektowania uniwersalnego w edukacji. Koncepcje te nie są jednak przedmiotem analizy w niniejszym opracowaniu. Celem artykułu jest próba odpowiedzi na pytanie, czy rozwiązania instytucjonalno-prawne w zakresie wsparcia procesu kształcenia osób z niepełnosprawnościami na poziomie wyższym znajdują odzwierciedlenie w akademickiej rzeczywistości. W tekście poszukuje się też odpowiedzi na pytania szczegółowe: o zakres wsparcia dla studentów z niepełnosprawnościami, o formalne ograniczenia uczestnictwa w kształceniu akademickim, o wpływ instrumentów wsparcia na uczelniany model pomocy w praktyce.

Przyjęta na potrzeby opracowania metodologia opiera się na różnorodności w obrębie metod jakościowych, co wydaje się przydatne w szukaniu odpowiedzi na tak postawione pytania. Chodzi tu o metodę komparatystyczną w analizie aktów prawnych, zastosowaną dla porównania obowiązującego ustawodawstwa i planowanych zmian prawnych oraz studium przypadku i obserwację uczestniczącą, które przydatne są w analizie systemu wsparcia kształcenia studentów i doktorantów z niepełnosprawnościami jednej z wybranych uczelni wyższej. 


\section{Niepełnosprawność w szkolnictwie wyższym}

Dostęp do powszechnego szkolnictwa wyższego osobom z niepełnosprawnościami gwarantuje Konwencja o prawach osób niepełnosprawnych przyjęta przez Zgromadzenie Ogólne Narodów Zjednoczonych w 2006 r. W myśl Konwencji osoby z niepełnosprawnościami to te, które „mają długotrwale naruszoną sprawność fizyczną, umysłową, intelektualną lub w zakresie zmysłów, co może, w oddziaływaniu z różnymi barierami, utrudniać im pełny i skuteczny udział w życiu społecznym, na zasadzie równości z innymi osobami” (Konwencja..., 2006). Polska, ratyfikując Konwencję w 2012 r., zobowiązała się do zapewnienia włączającego systemu kształcenia na wszystkich poziomach edukacji, w tym „dostępu do powszechnego szkolnictwa wyższego, szkolenia zawodowego, kształcenia dorosłych i możliwości uczenia się przez całe życie, bez dyskryminacji i na zasadzie równości z innymi osobami” (Ibidem). Czy rzeczywiście inkluzyjne i ogólnodostępne co do zasady uczelnie wyższe realizują te zapewnienia?

Na polskim gruncie prawnym edukacja i szkolenie osób z niepełnosprawnościami traktowane są jako element rehabilitacji zmierzającej do osiągnięcia, przy kreatywnym uczestnictwie tych osób, możliwie najwyższego poziomu funkcjonowania, jakości życia i integracji społecznej (Ustawa..., 1997). Ustawa o szkolnictwie wyższym (Ustawa..., 2005) nie zawiera definicji niepełnosprawności. Dopiero przy określaniu warunków świadczeń pomocy materialnej udzielanych osobom z niepełnosprawnościami odwołuje się ona do wspomnianej ustawy o rehabilitacji zawodowej i społecznej. Ta z kolei dotyczy osób, których niepełnosprawność została potwierdzona orzeczeniem: 1) o zakwalifikowaniu przez organy orzekające do jednego $\mathrm{z}$ trzech stopni, 2) o całkowitej lub częściowej niezdolności do pracy na podstawie odrębnych przepisów, 3) o niepełnosprawności, wydanym przed ukończeniem 16. roku życia (Ibidem). Zatem szkolnictwo wyższe odnosi się jedynie do niepełnosprawności $\mathrm{w}$ ujęciu prawnym. Można zauważyć, że nie jest to rozumienie zgodne $\mathrm{z}$ duchem Konwencji. Niemniej polskie unormowania prawne wzmacniają system wsparcia kształcenia osób z niepełnosprawnościami. Przy okazji warto zauważyć, że historia edukacji włączającej w szkołach wyższych jest znacznie dłuższa niż sankcjonujące ją przepisy prawa (Sztobryn-Giercuszkiewicz, 2018).

W roku akademickim 2016/2017 liczba studentów z niepełnosprawnościami wyniosła 25 074, w tym 15537 na studiach stacjonarnych oraz 9537 na studiach niestacjonarnych - stanowili oni 1,9 proc. wszystkich studentów (Szkoly wyższe..., 2017). W tym samym roku akademickim stypendia specjalne dla osób niepełnosprawnych pobierało 21,7 tys. osób, czyli 1,6 proc. wszystkich studiujących (Ibidem). Z kolei 
wskaźnik osób z wykształceniem wyższym wśród osób z niepełnosprawnościami kształtuje się na poziomie 10 proc. Współczynnik aktywności zawodowej osób z niepełnosprawnościami w wieku produkcyjnym w 2016 r. wyniósł 26,1 proc. ogółem oraz 51,4 proc. wśród osób z wykształceniem wyższym (Dane..., 2018). Niższa jest też stopa bezrobocia wśród osób z niepełnosprawnościami posiadających dyplom ukończenia studiów wyższych. Wykształcenie wyższe jest zatem czynnikiem zwiększającym szanse na zatrudnienie, na aktywny udział w życiu społeczno-zawodowym.

Zmiany zachodzące $\mathrm{w}$ obszarze kształcenia osób z niepełnosprawnościami na uczelniach wyższych nie są ocenianie jednoznacznie. Do dobrych praktyk należą pracownie usług cyfryzacji, biblioteki cyfrowe, poradnie zdrowia psychicznego, infrastruktura oparta na zasadzie projektowania uniwersalnego (Topolewska, 2018). Nie brakuje też głosów krytycznych, dotyczących m.in. wciąż stereotypowego postrzegania niepełnosprawności i niskiego poziomu wiedzy na temat potrzeb tej grupy czy dostępności niektórych kierunków i zajęć (Dostępność..., 2015).

\section{Rozwiązania legislacyjne}

Zmiana legislacyjna, będąca elementem reformowania systemu szkolnictwa wyższego, stanowi obecnie ważki temat dyskusji w środowisku akademickim. Również w tym opracowaniu podkreślono kluczową rolę ustawodawstwa, gdyż implikuje ono bieżące i planowane działania, podejmowane przez pracowników uczelni na rzecz wspierania studentów i doktorantów z niepełnosprawnościami. Rozwiązania prawne przedstawiam zatem jako tło do analizy infrastruktury i zasobów uczelni wyższej w obszarze kształcenia osób ze szczególnymi potrzebami. W tej części artykułu porównane zostaną zapisy obowiązującej ustawy i projektu Ustawy 2.0. w odniesieniu do osób z niepełnosprawnościami, z zaznaczeniem, że zaproponowana w tabeli 1 komparatystyka przepisów prawnych uwzględnia jedynie te aspekty, które według autorki mogą mieć znaczenie w kontekście przedmiotu niniejszego opracowania.

Tabela 1. Analiza porównawcza obowiązujących i planowanych regulacji prawnych w obszarze kształcenia osób z niepełnosprawnościami na poziomie szkolnictwa wyższego

\begin{tabular}{|l|l|l|}
\cline { 2 - 3 } \multicolumn{1}{c|}{} & \multicolumn{1}{c|}{$\begin{array}{c}\text { Ustawa z dnia } 27 \text { lipca } 2005 \mathrm{r} \text {. Prawo } \\
\text { 0 szkolnictwie wyższym }\end{array}$} & $\begin{array}{c}\text { Rządowy projekt ustawy Prawo o szkolnictwie } \\
\text { wyższym i nauce z dnia 22.01.2018 r. }\end{array}$ \\
\hline Terminologia & $\begin{array}{l}\text { Studenci i doktoranci będący } \\
\text { osobami niepełnosprawnymi/osoby } \\
\text { niepełnosprawne }\end{array}$ & Osoby z niepełnosprawnościami \\
\hline
\end{tabular}




\begin{tabular}{|c|c|c|}
\hline & $\begin{array}{c}\text { Ustawa z dnia } 27 \text { lipca } 2005 \text { r. Prawo } \\
\text { o szkolnictwie wyższym }\end{array}$ & $\begin{array}{l}\text { Rządowy projekt ustawy Prawo o szkolnictwie } \\
\text { wyższym i nauce z dnia 22.01.2018 r. }\end{array}$ \\
\hline $\begin{array}{l}\text { Podstawowe zadanie } \\
\text { uczelni }\end{array}$ & $\begin{array}{l}\text { Stwarzanie osobom niepełnosprawnym } \\
\text { warunków do pełnego udziału } \\
\text { w: a) procesie kształcenia, b) badaniach } \\
\text { naukowych }\end{array}$ & $\begin{array}{l}\text { Stwarzanie osobom z niepełnosprawnościami } \\
\text { warunków do pełnego udziału w procesie } \\
\text { przyjmowania na uczelnię w celu odbywania } \\
\text { kształcenia, w kształceniu, w prowadzeniu } \\
\text { działalności naukowej }\end{array}$ \\
\hline $\begin{array}{l}\text { Celowość } \\
\text { (finansowania) }\end{array}$ & $\begin{array}{l}\text { Zadania związane ze stwarzaniem } \\
\text { studentom i doktorantom będącym } \\
\text { osobami niepełnosprawnymi warunków } \\
\text { do pełnego udziału w procesie kształcenia }\end{array}$ & $\begin{array}{l}\text { Zadania związane z zapewnieniem osobom } \\
\text { z niepełnosprawnościami warunków do } \\
\text { pełnego udziału w procesie przyjmowania } \\
\text { na studia, do szkół doktorskich, kształcenia } \\
\text { na studiach i w szkołach doktorskich lub } \\
\text { prowadzenia działalności naukowej }\end{array}$ \\
\hline Forma finansowania & $\begin{array}{l}\text { Dotacja na zadania związane ze } \\
\text { stwarzaniem studentom i doktorantom } \\
\text { będącym osobami niepełnosprawnymi } \\
\text { warunków do pełnego udziału w procesie } \\
\text { kształcenia }\end{array}$ & $\begin{array}{l}\text { Fundusz wsparcia osób } \\
\text { z niepełnosprawnościami }\end{array}$ \\
\hline $\begin{array}{l}\text { Kwalifikowalność } \\
\text { wydatków }\end{array}$ & $x$ & $x$ \\
\hline Regulamin studiów & $\begin{array}{l}\text { Uwzględnia warunki właściwej realizacji } \\
\text { procesu dydaktycznego z uwzględnieniem } \\
\text { szczególnych potrzeb studentów będących } \\
\text { osobami niepełnosprawnymi }\end{array}$ & $x$ \\
\hline Proces dydaktyczny & $\begin{array}{l}\text { Regulamin studiów w uczelniach } \\
\text { uwzględnia warunki właściwej realizacji } \\
\text { procesu dydaktycznego, z uwzględnieniem } \\
\text { szczególnych potrzeb studentów będących } \\
\text { osobami niepełnosprawnymi }\end{array}$ & $x$ \\
\hline Rekrutacja na studia & $\begin{array}{l}\text { Warunki i tryb rekrutacji w przypadku } \\
\text { egzaminów wstępnych powinny } \\
\text { uwzgledniać szczególne potrzeby } \\
\text { kandydatów na studia będących osobami } \\
\text { niepełnosprawnymi }\end{array}$ & $x$ \\
\hline Pomoc materialna & $\begin{array}{l}\text { Stypendium specjalne dla osób } \\
\text { niepełnosprawnych może otrzymywać } \\
\text { student z tytułu niepełnosprawności } \\
\text { potwierdzonej orzeczeniem właściwego } \\
\text { organu }\end{array}$ & $\begin{array}{l}\text { Stypendium dla osób } \\
\text { z niepełnosprawnościami może } \\
\text { otrzymać student posiadający orzeczenie } \\
\text { o niepełnosprawności, orzeczenie o stopniu } \\
\text { niepełnosprawności albo orzeczenie, } \\
\text { o którym mowa w ustawie o rehabilitacji } \\
\text { zawodowej i społecznej oraz zatrudnianiu } \\
\text { osób niepełnosprawnych }\end{array}$ \\
\hline $\begin{array}{l}\text { Stypendium na drugim } \\
\text { kierunku studiów }\end{array}$ & $x$ & $\begin{array}{l}\text { Osoby na drugim kierunku będą } \\
\text { mogły pobierać stypendium dla osób } \\
\text { z niepełnosprawnościami, jeśli nie pobierały } \\
\text { na pierwszym - dotyczy to osób, które } \\
\text { nabyły niepełnosprawność w trakcie lub } \\
\text { po ukończeniu studiów }\end{array}$ \\
\hline $\begin{array}{l}\text { Doktoranci } \\
\text { z niepełnosprawnościami }\end{array}$ & $x$ & $\begin{array}{l}\text { Stypendium doktoranckie } \\
\text { w wysokości zwiększonej o } 30 \text { proc. }\end{array}$ \\
\hline
\end{tabular}

Źródło: opracowanie własne. 
Przede wszystkim podkreślić należy zmianę paradygmatu w zakresie stosowanej terminologii (nie „osoby niepełnosprawne”, a „osoby z niepełnosprawnościami”), wprowadzonej na etapie konsultacji społecznych projektu². Ustawodawca planuje rozszerzyć katalog odbiorców wsparcia (nie tylko studenci i doktoranci, ale wszystkie osoby z niepełnosprawnościami, a zatem także kandydaci na studia, słuchacze studiów podyplomowych, pracownicy?) i podstawowe zadania uczelni (o proces rekrutacji na studia). Projekt ustawy zawiera także zmiany w zakresie sposobu finansowania systemu wsparcia udzielanego szkołom wyższym. Dotychczasowa dotacja na zadania związane ze stwarzaniem studentom i doktorantom będącym osobami niepełnosprawnymi warunków do pełnego udziału w procesie kształcenia zostanie przekształcona w Fundusz wsparcia osób z niepełnosprawnościami, obsługiwany przez Bank Gospodarstwa Krajowego. Z kolei zapisy dotyczące pomocy materialnej dla osób z niepelnosprawnościami wprowadzają zmiany na rzecz doprecyzowania rodzajów orzeczeń uprawniających do otrzymywania stypendium, doprecyzowania warunków pobierania stypendium na drugim kierunku studiów oraz zwiększenia stypendium doktoranckiego o 30 proc. Porównując obowiązujące przepisy z założeniami nowej ustawy, należy uwzględniać $\mathrm{z}$ jednej strony pewne nieścisłości w przedstawionym projekcie, na przykład niespójność między podstawowymi zadaniami uczelni a przedmiotem dotacji lub brak odniesienia zadania „Stworzenie warunków do pełnego udziału w procesie przyjmowania na studia" w zapisach dotyczących organizacji warunków i trybu rekrutacji, z drugiej zaś strony należy mieć na uwadze niezakończony proces legislacyjny.

Przedstawione rozwiązania instytucjonalno-prawne wskazują kierunki rozwoju polityki kształcenia osób z niepełnosprawnościami na poziomie wyższym. W wymiarze praktycznym zmiany te determinują bieżące działania uczelnianych zespołów, zwłaszcza w zakresie możliwości realizacji zadań finansowanych ze środków rządowych, na podstawie których budżet owych zespołów skonstruowano ${ }^{3}$.

\section{System wsparcia w praktyce - studium przypadku}

W części praktycznej artykułu nakreślony zostanie polski system wsparcia studentów i doktorantów z niepełnosprawnościami na przykładzie wybranej uczelni

2 Za propozycją stosowania w nowej ustawie terminu „osoby z niepełnosprawnościami” optowały liczne organizacje pozarządowe, m.in. Fundacja Instytut Rozwoju Regionalnego, która w tej sprawie wystosowała do wicepremiera Jarosława Gowina pismo podpisane przez 56 sygnatariuszy ze środowisk uczelni i osób z niepełnosprawnościami.

3 Szerzej o znaczeniu nakładów finansowych w procesie reformowania szkolnictwa wyższego, a także o relacji strategia versus prawo w projektowaniu i wdrażaniu omawianej polityki sektorowej zobacz Dziedziczak-Foltyn (2018). 
wyższej - Uniwersytetu Wrocławskiego. Wybór ten nie jest przypadkowy, wynika ze znajomości badanego środowiska. Autorka artykułu miała okazję uczestniczyć $\mathrm{w}$ tworzeniu systemu wsparcia dla studentów z niepełnosprawnościami na Uniwersytecie Wrocławskim, a jej wnioski są wynikiem własnych obserwacji i doświadczeń zawodowych. Ponadto za przedmiotem opisu przemawiają:

1. Zakres i struktura systemu wsparcia. Podmiotowy system wsparcia tworzą władze uczelni, pełnomocnicy rektora, pracownicy jednostek administracji, wykładowcy, psycholodzy, doradcy zawodowi; zakres przedmiotowy tworzą wewnętrzne akty normatywne, wypracowane formy wsparcia i dobre praktyki.

2. Liczebność studentów i doktorantów z niepełnosprawnościami. Według sprawozdania GUS S-10 w 2017 r. na Uniwersytecie Wrocławskim studiowało na studiach stacjonarnych 291 osób z niepełnosprawnościami (wszyscy studiujący to 19 915) oraz 75 osób na studiach niestacjonarnych (wszyscy studiujący to 5634), a zatem stosunek studentów z niepełnosprawnościami do liczby studentów ogółem nie odbiega od średniej krajowej".

System wsparcia na Uniwersytecie Wrocławskim współtworzy pełnomocnik rektora ds. studentów i doktorantów z niepełnosprawnością oraz pełnomocnik rektora ds. podnoszenia jakości kształcenia studentów z niepełnosprawnością, którzy reprezentują interesy studiujących zarówno przed jednostkami uniwersyteckimi, jak i zewnętrznymi. Pełnomocnicy udzielają indywidualnych konsultacji studentom z różnymi rodzajami niepełnosprawności i podejmują działania w zakresie dostosowania procesu kształcenia do ich potrzeb w ramach obowiązującego Regulaminu studiów (Obwieszczenie..., 2016). Wymieniony dokument obowiązuje wszystkich studentów, natomiast studentom $\mathrm{z}$ niepełnosprawnościami zapewnia prawo do:

- szczególnych warunków uczestnictwa w zajęciach oraz indywidualnych form i terminów ich zaliczania,

- uczestnictwa na szczególnych zasadach w indywidualnych programach studiów,

- ułatwień w studiowaniu, m.in. w formie indywidualnej organizacji studiów,

- pierwszeństwa w zapisach na zajęcia i w wyborze grup zajęciowych,

- indywidualnych warunków korzystania z bibliotek, określonych w regulaminach udostępniania zbiorów poszczególnych bibliotek,

- stosownej pomocy w pozyskiwaniu materiałów dydaktycznych i sprzętu niezbędnego do studiowania,

4 Zaznaczyć należy, że podane dane liczbowe nie uwzględniają osób niezdiagnozowanych, nieposiadających orzeczeń oraz tych, które nie ujawniają informacji o swojej niepełnosprawności. Podanie przez studenta informacji o posiadanej niepełnosprawności jest dobrowolne. Przedstawienie orzeczenia jest natomiast warunkiem ubiegania się o stypendium specjalne dla osób niepełnosprawnych. 
- używania na zajęciach środków wspomagających proces kształcenia, np. urządzeń rejestrujących,

- indywidualnych konsultacji, a w uzasadnionych przypadkach także indywidualnych zajęć,

- indywidualnej opieki wybranego nauczyciela akademickiego.

Indywidualny plan studiów i programów kształcenia studentów z niepełnosprawnościami realizowany jest zgodnie z zasadami ustalonymi przez radę wydziału. W uzasadnionych i udokumentowanych przypadkach dziekan może wyrazić zgodę na eksternistyczne zaliczanie przez studenta niektórych modułów zajęć. Dodatkowo, na wniosek studenta, prowadzący zajęcia ustala indywidualny termin i formę zaliczenia. Studenci z ograniczeniami zdrowotnymi realizują zajęcia wychowania fizycznego w ramach grup rehabilitacyjnych; ćwiczenia korekcyjno-kompensacyjne, ćwiczenia relaksacyjno-oddechowe, przy uwzględnieniu typu ograniczenia i zaleceń lekarza (Zarządzenie nr 98, 2017).

System wsparcia realizuje jednostka administracyjna - Zespół ds. Obsługi Studentów i Doktorantów z Niepełnosprawnościami, podejmujący działania na rzecz likwidowania barier społecznych, komunikacyjnych i architektonicznych w środowisku akademickim. Podstawowe działanie Zespołu ukierunkowane jest na diagnozowanie potrzeb studentów i doktorantów z niepełnosprawnościami oraz dostosowanie i organizowanie form wsparcia.

Ze względu na niedookreślone przepisy prawne, dotyczące przeznaczania i kwalifikowalności wydatków (tabela 1) z dotacji na zadania związane ze stwarzaniem studentom i doktorantom będącym osobami niepełnosprawnymi warunków do pełnego udziału w procesie kształcenia Zespół, wzorując się na dobrych praktykach w środowisku akademickim ${ }^{5}$, wypracował własny katalog form wsparcia:

- pomoc asystentów dydaktycznych,

- transport na zajęcia dydaktyczne i do miejsca zamieszkania,

- indywidualne lektoraty języka obcego objętego programem studiów,

- tłumacz języka migowego,

- kurs orientacji przestrzennej dla studentów niewidomych i niedowidzących,

- adaptacja i przetwarzanie materiałów dydaktycznych,

- wypożyczalnia specjalistycznego sprzętu dla osób z niepełnosprawnością ruchu, słuchu, wzroku,

- poradnia psychologiczna dla studentów i doktorantów z niepełnosprawnością,

5 Na przykład rekomendacje Fundacji Instytut Rozwoju Regionalnego, Projekt dobrych praktyk Komisji ds. Wyrównywania Szans Edukacyjnych przy Konferencji Rektorów Akademickich Szkół Polskich i wiele innych. 
- wyjazdy szkoleniowo-integracyjne,

- doradztwo zawodowe,

- dostosowana strona internetowa uczelni,

- konsultacje dla kandydatów na studia.

Warunki przyznawania świadczeń określa Regulamin przyznawania na Uniwersytecie Wrocławskim dofinansowania ze środków dotacji z budżetu państwa na zadania związane ze stwarzaniem studentom i doktorantom będącym osobami niepełnosprawnymi warunków do pełnego udziału w procesie kształcenia (Zarządzenie nr 114, 2012). Dokument ten zawiera informacje przydatne dla samych zainteresowanych, precyzuje bowiem odbiorców wsparcia (kto), przedmiot pomocy (co), procedurę przyznania (jak).

W działalność na rzecz studentów i doktorantów z niepełnosprawnościami zaangażowane są inne jednostki uniwersyteckie. W Biurze Karier, podczas spotkania z doradcą zawodowym lub specjalistą rynku pracy, student może określić ścieżkę rozwoju, odbyć sesję coachingową, zbadać preferencje i predyspozycje zawodowe, omówić plany zawodowe czy zasady aplikowania o pracę; w Biurze Współpracy Międzynarodowej otrzymać informacje w zakresie dostępności programów wymiany międzynarodowej; w poradni psychologicznej uzyskać pomoc w stanach lęku, stresu, przeciążenia.

Ideę edukacji włączającej na poziomie szkolnictwa wyższego realizują wykładowcy, którzy pracują ze studentami na co dzień. Wzrastająca liczba studentów z zaburzeniami psychicznymi spowodowała konieczność wprowadzenia innowacyjnych metod pracy, zastosowania technik nauczania umożliwiających efektywną realizację kursów, definiowania nowych wyzwań i pracy nad możliwymi rozwiązaniami. Szkolenia dla prowadzących zajęcia dydaktyczne są realizowane w ramach projektu „Dobra Kadra - podniesienie kompetencji kadry dydaktycznej Uniwersytetu Wrocławskiego na rzecz wzmocnienia jakości kształcenia na uczelni”, współfinansowanego ze środków Unii Europejskiej w ramach Europejskiego Funduszu Społecznego.

W kontekście omawiania usprawnień procesu kształcenia studentów z niepełnosprawnością istotne jest nie tylko: kto i w jaki sposób prowadzi zajęcia, ale także: gdzie? Pytanie o dostępność architektoniczną budynków uniwersyteckich, sal wykładowych i ćwiczeniowych, dziekanatów wydaje się podstawowe, jednak często niedostępność ta stanowi barierę w procesie studiowania. W wyniku własnych obserwacji i rozmów $\mathrm{z}$ administratorami ustalono, że budynki Uniwersytetu Wrocławskiego są jedynie częściowo dostosowane do potrzeb osób z niepełnosprawnościami. Adaptację architektoniczną z pewnością utrudnia specyfika poszczególnych obiektów, ich położenie, stan, wartość historyczna i zabytkowa. Pozytywny przykład stanowią natomiast oznakowania brajlowskie jednostek administracyjnych i sal wykładowych na wszystkich 
wydziałach oraz mobilne i dostosowane do potrzeb osób z dysfunkcjami stanowiska laboratoryjne na Wydziale Chemii (Laboratorium..., 2018).

$* * *$

Czy na podstawie przedstawionego studium przypadku można wnioskować o polskim modelu systemu wsparcia kształcenia osób z niepełnosprawnościami na poziomie szkolnictwa wyższego? W tym względzie należy zachować ostrożność, niniejsze opracowanie nie zawiera pełnej analizy tego obszaru. By takiej dokonać, należałoby obraz wsparcia uzupełnić o badania, które uwzględnią perspektywę samych odbiorców. Ponadto model wsparcia uczelni różnicuje jej specyfika, liczba studentów i doktorantów z niepełnosprawnościami, zasoby finansowe i kadrowe uczelni, wreszcie, a może przede wszystkim (zmieniające się) regulacje prawne. Zaprezentowany model został oparty na ustawodawstwie z 2005 r. Porównanie dotychczas obowiązujących przepisów z projektem Ustawy 2.0. nie wskazuje na daleko idące zmiany, nie stanowi też pełnej odpowiedzi na potrzeby interesariuszy. Ponowna luka prawna, na przykład dotycząca kwalifikowalności wydatków, spowoduje konieczność wypracowania własnych praktyk i rozwiązań.

Przedstawione w artykule studium przypadku pozwala sformułować pewne ogólne wnioski. Główne ograniczenia pełnego uczestnictwa w życiu akademickim, wynikające z obowiązującego ustawodawstwa, to uzależnianie udzielanego wsparcia od orzecznictwa, co oznacza wykluczenie studentów o specjalnych potrzebach edukacyjnych nieposiadających orzeczeń; brak wytycznych wydatkowania dotacji budżetowej, co generuje zachowawczość i ograniczenie zakresu pomocy; wreszcie bariery architektoniczne, które powodują niedostępność infrastruktury dla osób z ograniczeniami ruchowymi. Sformułowane tu rekomendacje powinny zostać uwzględnione przez ustawodawcę, głównie z uwagi na kluczowy wpływ instrumentów prawnych na praktykę organizowania form pomocy w procesie kształcenia akademickiego.

\section{Bibliografia}

Dane dotyczące wykształcenia osób niepetnosprawnych na podstawie BAEL. (2018).

Dostępność edukacji akademickiej dla osób z niepełnosprawnościami (2015). Biuletyn Rzecznika Praw Obywatelskich, nr 5.

Dziedziczak-Foltyn, A. (2018). Reformy w polskim szkolnictwie wyższym po $1990 \mathrm{r}$. w świetle nauki o polityce publicznej. Studia z Polityki Publicznej, nr 2(18).

Kubacki, P. (2015). Polityka publiczna wobec niepełnosprawności - propozycje perspektyw teoretycznych. Studia z Polityki Publicznej, nr 4(8). 
Laboratorium bez barier. https://www.chem.uni.wroc.pl/Laboratorium_bez_barier?mid=110

Moroń, D. (2014). Studenci niepełnosprawni na publicznych i niepublicznych uczelniach. Wrocławskie Studia Politologiczne, nr 1.

Obwieszczenie Rektora Uniwersytetu Wrocławskiego z dnia 18 maja 2016 r. w sprawie ogłoszenia tekstu jednolitego uchwały nr 26/2015 Senatu uniwersytetu Wrocławskiego w sprawie Regulaminu studiów w Uniwersytecie Wrocławskim.

Odpowiedzialne wsparcie a zrównoważony rozwój, czyli o siedmiu zasadach wsparcia edukacyjnego będących filarami edukacji włączającej w szkolnictwie wyższym. (2018). Perdeus-Białek, M. (red.). Kraków: Dział ds. Osób Niepełnosprawnych Uniwersytetu Jagiellońskiego.

Szkoły wyższe i ich finanse w 2016 r. (2017). Warszawa: Główny Urząd Statystyczny, Informacje i opracowania statystyczne.

Sztobryn-Giercuszkiewicz, J. (2018). Szanse i ograniczenia kształcenia akademickiego osób z niepełnosprawnościami w Polsce - perspektywa socjologiczna. Łódź: Wydawnictwo Politechniki Łódzkiej.

Topolewska, M. (2018). Uczelnie bez barier i przyjazne osobom niepełnosprawnym. Dziennik Gazeta Prawna, nr 114.

\section{Akty prawne}

Konwencja o prawach osób niepełnosprawnych sporządzona w Nowym Jorku dnia 13 grudnia 2006 r., Dz. U. 2012, poz. 1196.

Obwieszczenie Rektora Uniwersytetu Wrocławskiego z dnia 18 maja 2016 r. w sprawie ogłoszenia tekstu jednolitego uchwały nr 26/2015 Senatu uniwersytetu Wrocławskiego w sprawie Regulaminu studiów w Uniwersytecie Wrocławskim.

Rządowy projekt ustawy Prawo o szkolnictwie wyższym i nauce, Projekt z dnia 22.01.2018 r.

Ustawa z dnia 27 lipca 2005 r. Prawo o szkolnictwie wyższym, Dz. U. 2005, nr 164, poz. 1365.

Ustawa z dnia 27 sierpnia 1997 r. o rehabilitacji zawodowej i społecznej oraz zatrudnianiu osób niepełnosprawnych, Dz. U. 1997, nr 123, poz. 776.

Zarządzenie nr 98/2017 Rektora Uniwersytetu Wrocławskiego z dnia 15 września 2017 r. w sprawie wprowadzenia Regulaminu organizacji zajęć i zaliczeń wychowania fizycznego w Uniwersytecie Wrocławskim.

Zarządzenie nr 114/2012 Rektora Uniwersytetu Wrocławskiego z dnia 27 września 2012 r. wprowadzające Regulamin przyznawania w Uniwersytecie Wrocławskim dofinansowania ze środków dotacji z budżetu państwa na zadania związane ze stwarzaniem studentom i doktorantom, będącym osobami niepełnosprawnymi warunków do pełnego udziału $\mathrm{w}$ procesie kształcenia. 
